\title{
ANALISIS KOMPATIBILITAS CAMPURAN PELUMAS INDUSTRI (MESIN DAN HIDROLIK) DARI BAHAN DASAR MINERAL DAN SINTETIK
}

\author{
Rini Siskayanti ${ }^{1)}$, Muhamad Engkos Kosim ${ }^{1)}$ \\ 1) Program Studi Teknik Kimia Fakultas Teknik Universitas Muhammadiyah Jakarta \\ rininovar@gmail.com
}

\begin{abstract}
One of the most important components of the performance of an engine is lubricating oil or so-called oil. Lubricating oil serves to reduce the friction between components which could result in damage to the machine. With the development of technology today various brands of lubricants of the same type or different each market. Highly recommended to conduct compatibility analysis laboratory prior to mixing to ensure that the lubricant can dissolve well (compatible). Mixing two incompatible types of lubricants may be one of the main causes of the engine failure and lubricants. In this study, the lubricant used is that of industrial lubricants and hydraulic engine lubricants. Compatibility test performed in the laboratory with test method ASTM D-7155. In this study sample was made with a mixed composition 0: 100, 20:80, 50:50, 80:20 and 100: 0. Observations made during the 7 days on two conditions, namely a temperature of $65^{\circ} \mathrm{C}$ and room temperature. The results showed that the industrial engine lubricant monograde (SAE 40) and multigrade (SAE 80W-90) on the basis of mineral materials compatible when mixed with mineral basic ingredients are the same. While the mineral monograde engine oil sample is mixed with synthetic been observed starting on day 6 at $65^{\circ} \mathrm{C}$ there are deposits on the composition of 50:50 and 80:20. This indicates that the lubricant samples not compatible and can not be done when used on the mixing machine. In the research mix hydraulic oil ISO VG 46 and ISO VG 32 with minerals, all compositions contained no precipitate and separation does not occur during the observation. Lubricants looks clean and can dissolve well (compatible)
\end{abstract}

Keywords: industrial lubricants, hydraulic oil, engine oil, lubricant compatibility

ABSTRAK. Salah satu komponen yang terpenting dari kinerja sebuah mesin adalah minyak pelumas atau yang biasa disebut oli. Minyak pelumas berfungsi mengurangi terjadinya gesekan-gesekan antar komponen yang dapat mengakibatkan kerusakan pada mesin. Dengan berkembangnya teknologi saat ini berbagai merk pelumas dari jenis yang sama maupun yang berbeda semakin banyak beredar dipasaran. Sangat dianjurkan untuk melakukan analisis kompatibilitas dilaboratorium sebelum melakukan pencampuran untuk memastikan bahwa pelumas dapat larut dengan baik (kompatibel). Pencampuran dua jenis pelumas yang tidak kompatibel dapat menjadi salah satu penyebab utama terjadinya kegagalan mesin dan pelumas. Pada penelitian ini pelumas yang digunakan adalah pelumas industri yaitu dari jenis pelumas mesin dan hidrolik. Uji kompatibilitas dilakukan di laboratorium dengan metode pengujian ASTM D-7155. Pada penelitian ini sampel dibuat dengan komposisi campuran 0:100, 20:80, 50:50, 80:20, dan 100:0. Pengamatan dilakukan selama 7 hari pada dua kondisi suhu yaitu suhu $65^{\circ} \mathrm{C}$ dan suhu kamar. Hasil pengamatan menunjukkan bahwa pelumas mesin industri monograde (SAE 40) dan multigrade (SAE 80W-90) dari bahan dasar mineral kompatibel jika dicampur dengan bahan dasar mineral yang sama. Sedangkan pada sampel pelumas mesin monograde mineral dicampur dengan sintetik setelah diamati mulai hari ke-6 pada suhu $65^{\circ} \mathrm{C}$ terdapat endapan pada komposisi 50:50 dan 80:20. Hal ini menunjukkan bahwa sampel pelumas tersebut tidak kompatibel dan tidak dapat dilakukan pencampuran pada saat digunakan pada mesin. Pada penelitian campuran pelumas hidrolik ISO VG 46 dan ISO VG 32 dengan bahan mineral, semua komposisi tidak terdapat endapan dan tidak terjadi pemisahan selama pengamatan. Pelumas terlihat bersih dan dapat larut dengan baik (kompatibel)

Kata kunci: pelumas industri, pelumas hidrolik, pelumas mesin, kompatibilitas pelumas 


\section{PENDAHULUAN}

Pelumas atau yang biasa disebut oli merupakan salah satu bagian terpenting yang tak terpisahkan dari suatu mesin atau peralatan yang bergerak. Fungsi utama pelumas adalah mencegah atau mengurangi keausan sebagai akibat dari kontak langsung antara permukaan logam yang satu dengan permukaan logam yang lain.

Berdasarkan data dari Badan Pusat Statistik Nasional dan Gabungan dari Industri Kendaraan Bermotor, konsumsi pelumas di Indonesia meningkat sekitar $10.1 \%$ per tahun. Sejak diberlakukannya Keppres No. 21/2001 tentang Penyediaan dan Pelayanan Pelumas, mengakhiri monopoli Pertamina. Berbagai merk pelumas baik pelumas kendaraan maupun pelumas industri dari jenis yang sama maupun yang berbeda semakin banyak beredar dipasaran. Dengan adanya perkembangan teknologi di segala bidang, pelumas pun semakin berkembang baik dari variasi jenis produk maupun kualitasnya. Saat ini banyak beredar pelumas sintetis yang mempunyai sifat lebih unggul dibandingkan pelumas mineral. Selain dapat memberikan banyak pilihan terhadap pemakai pelumas, banyaknya variasi jenis pelumas ini juga dapat menimbulkan beberapa masalah. Salah satu masalah umum yang sering terjadi adalah ketika terjadi pencampuran baik sengaja maupun yang tidak disengaja terhadap pelumas yang memiliki paket aditif atau minyak dasar yang berbeda. Beberapa pendapat menyatakan bahwa pencampuran pelumas ini tidak menimbulkan masalah terutama jika berasal dari bahan dasar yang sama. Tetapi pendapat lain menyatakan bahwa pencampuran dua jenis pelumas yang berbeda ini dapat menjadi salah satu penyebab utama terjadinya kegagalan mesin sehingga menyebabkan terhentinya produksi pada industri. Hal ini dapat disebabkan karena beberapa masalah yang timbul antara lain pelumas tidak kompatibel atau tidak dapat larut dengan baik jika ada perbedaan dari minyak dasar (base oil), atau karena terjadi kebocoran dan kegagalan seal akibat pelumas yang tidak sesuai dengan mesin.

Pelumas tidak kompatibel karena adanya perbedaan paket aditif. Bahan tidak larut dalam sistem sirkulasi menyebabkan aditif tidak dapat bekerja maksimal. Akibatnya dapat timbul slugde, hilangnya kinerja aditif antiwear, serta berkurangnya stabilitas oksidasi pada mesin. Dengan demikian kinerja mesin secara keseluruhan dapat terganggu yang pada akhirnya terjadi kegagalan mesin.

Campuran produk yang tidak sejenis ini paling sering terjadi pada pemakaian pelumas industri seperti pelumas hidrolik dan pelumas mesin. Pencampuran kemungkinan dapat terjadi saat konsumen mengubah merk pelumas yang biasa dipakai dari salah satu pemasok kemudian beralih ke merk pelumas yang lain. Hal ini terjadi karena didorong oleh faktor ekonomi, kinerja pelumas yang buruk, masalah operator mesin, prospek peningkatan kinerja pelumas atau produk yang digunakan sudah tidak diproduksi lagi. Pencampuran pelumas yang tidak disengaja dikarenakan kurangnya identifikasi pelumas dilapangan, penanganan dan penyimpanan pelumas yang tidak benar atau bisa disebabkan karena kurangnya pengetahuan dari operator itu sendiri. Tetapi, dalam banyak kasus pencampuran pelumas di industri terjadi karena kurangnya pengetahuan pemakai tentang konsekuensi negatif yang mungkin terjadi. Untuk memastikan mengenai kompatibilitas pencampuran pelumas yang berbeda diatas, diperlukan penelitian mengenai uji kompatibilitas terhadap beberapa jenis pelumas baik dari bahan sintetis maupun mineral. Penelitian ini dilakukan dengan pencampuran produk minyak pelumas industri mesin dan hidrolik dari beberapa jenis merk dengan bahan dasar yang berbeda. Sampel yang diamati adalah campuran pelumas mineral dan mineral, campuran pelumas mineral dan sintetis. Dua produk dicampur dengan berbagai konsentrasi dan diamati apakah terjadi endapan atau sedimen. Pengamatan dilakukan pada suhu kamar dan suhu 
$65^{\circ} \mathrm{C}$ dengan waktu yang berbeda selama 7 hari. Uji kompatibilitas dilakukan di laboratorium dengan metode pengujian ASTM D-7155.

Hasil yang ingin dicapai dari penelitian ini adalah mampu mengetahui kompatibilitas pelumas dari berbagai jenis dan merk yang berbeda sehingga tidak terjadi lagi perbedaan dan dapat mencegah terjadinya kegagalan mesin akibat dari pelumas.

\section{METODOLOGI PENELITIAN}

Penelitian ini dilakukan dengan cara pencampuran produk minyak pelumas industri dari beberapa jenis pelumas mesin dan hidrolik dengan bahan dasar yang berbeda. Campuran dibuat dalam beberapa komposisi perbandingan yaitu komposisi $A(0: 100)$, komposisi $B(20: 80)$, komposisi $C$ (50:50), komposisi $D(80: 20)$ dan komposisi E (100:0) Masing -masing komposisi dibuat 200 gram kemudian dibagi dua dan ditempatkan pada beaker glass. Satu sampel diletakkan pada suhu ruang dan satu sampel lagi dimasukkan kedalam oven dengan suhu $65^{\circ} \mathrm{C}$. Kemudian dilakukan pengamatan uji kompatibilitas selama 7 hari. Metode uji kompatibilitas menggunakan ASTM D7155.

Penelitian yang dilakukan dijelaskan melalui diagram alir berikut :

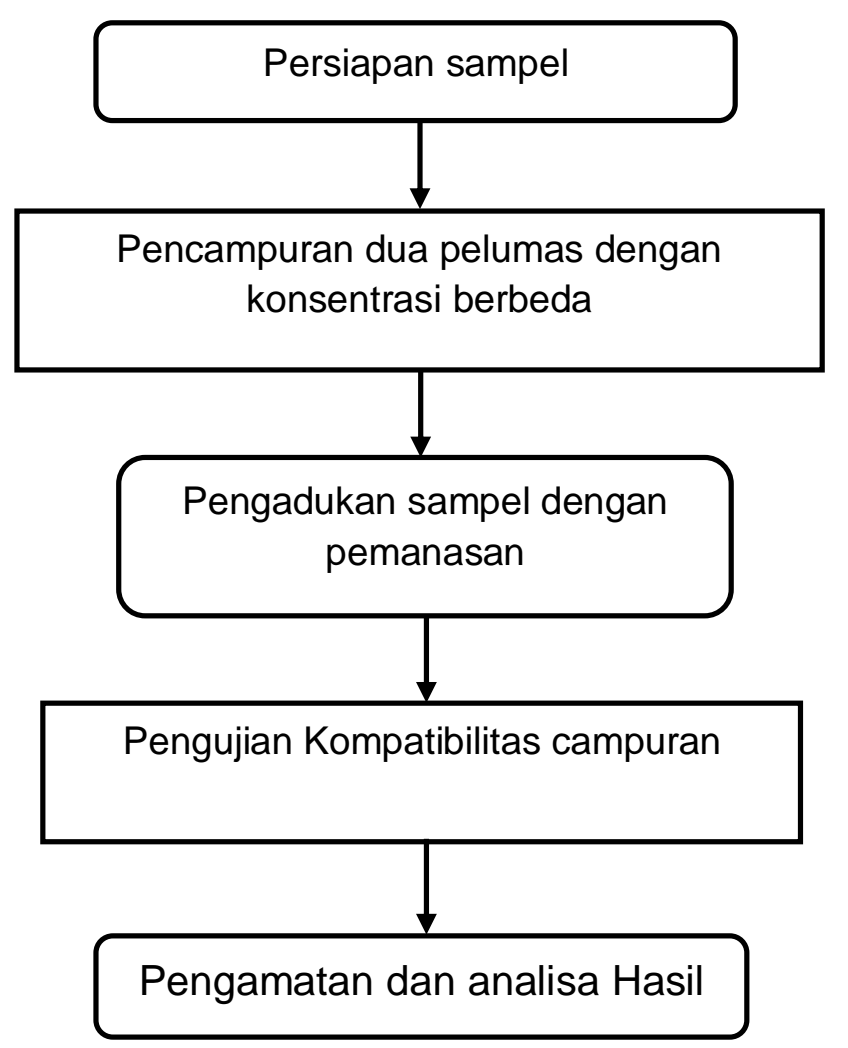

Gambar 1. Diagram Alir Penelitian

\section{HASIL DAN PEMBAHASAN}

Pada penelitian ini pengamatan dilakukan pada dua kondisi suhu yaitu suhu $65^{\circ} \mathrm{C}$ dan suhu kamar. Bahan baku yang telah disiapkan kemudian ditimbang sesuai komposisi yang dibutuhkan kemudian dilakukan pemanasan di penangas (hot plate) sambil dilakukan pengadukan dengan magnetic stirrer sampai bahan baku tercampur homogen. Kemudian 
dilakukan pengamatan selama tujuh hari pada masing- masing sampel.

\section{Hasil Penelitian}

Komposisi campuran pelumas yang dibuat dapat dilihat pada tabel 1 dibawah ini:

Tabel 1. Komposisi campuran pelumas

\begin{tabular}{|c|c|c|c|c|c|c|}
\hline \multirow{2}{*}{ No. } & \multirow{2}{*}{ Sampel } & \multicolumn{5}{|c|}{ Komposisi Campuran Pelumas } \\
\hline & & Camp A & Camp B & Camp C & Camp D & Camp E \\
\hline \multirow{2}{*}{1} & Mineral \& & 0 & 20 & 50 & 80 & 100 \\
\hline & Mineral & 100 & 80 & 50 & 20 & 0 \\
\hline \multirow{2}{*}{2} & Mineral \& & 0 & 20 & 50 & 80 & 100 \\
\hline & Sintetik & 100 & 80 & 50 & 20 & 0 \\
\hline \multirow{2}{*}{3} & Sintetik \& & 0 & 20 & 50 & 80 & 100 \\
\hline & Sintetik & 100 & 80 & 50 & 20 & 0 \\
\hline
\end{tabular}

Setelah dilakukan pengamatan terhadap sampel diatas, diperoleh data-data yang dapat dilihat pada tabel 2 dibawah ini :

Tabel 2. Data hasil pengamatan kompatibilitas campuran oli mesin mineral dan mineral (SAE 40)

\begin{tabular}{|c|c|c|c|c|}
\hline \multirow[t]{2}{*}{ PENGAMATAN } & \multicolumn{2}{|c|}{ 3. CAMPURAN C } & \multicolumn{2}{|c|}{ 4. CAMPURAN D } \\
\hline & SUHU KAMAR & $65^{\circ} \mathrm{C}$ & SUHU KAMAR & $65^{\circ} \mathrm{C}$ \\
\hline \multirow{3}{*}{ HARI 1} & Tdk ada endapan & Tdk ada endapan & Tdk ada endapan & Tdk ada endapan \\
\hline & Tdk ada pemisahan & Tdk ada pemisahan & Tdk ada pemisahan & Tdk ada pemisahan \\
\hline & Bersih & Bersih & Bersih & Bersih \\
\hline \multirow{3}{*}{ HARI 2} & Tdk ada endapan & Tdk ada endapan & Tdk ada endapan & Tdk ada endapan \\
\hline & Tdk ada pemisahan & Tdk ada pemisahan & Tdk ada pemisahan & Tdk ada pemisahan \\
\hline & Bersih & Bersih & Bersih & Bersih \\
\hline \multirow{3}{*}{ HARI 3} & Tdk ada endapan & Tdk ada endapan & Tdk ada endapan & Tdk ada endapan \\
\hline & Tdk ada pemisahan & Tdk ada pemisahan & Tdk ada pemisahan & Tdk ada pemisahan \\
\hline & Bersih & Bersih & Bersih & Bersih \\
\hline \multirow{3}{*}{ HARI 4} & Tdk ada endapan & Tdk ada endapan & Tdk ada endapan & Tdk ada endapan \\
\hline & Tdk ada pemisahan & Tdk ada pemisahan & Tdk ada pemisahan & Tdk ada pemisahan \\
\hline & Bersih & Bersih & Bersih & Bersih \\
\hline \multirow{3}{*}{ HARI 5} & Tdk ada endapan & Tdk ada endapan & Tdk ada endapan & Tdk ada endapan \\
\hline & Tdk ada pemisahan & Tdk ada pemisahan & Tdk ada pemisahan & Tdk ada pemisahan \\
\hline & Bersih & Bersih & Bersih & Bersih \\
\hline \multirow{3}{*}{ HARI 6} & Tdk ada endapan & Tdk ada endapan & Tdk ada endapan & Tdk ada endapan \\
\hline & Tdk ada pemisahan & Tdk ada pemisahan & Tdk ada pemisahan & Tdk ada pemisahan \\
\hline & Bersih & Bersih & Bersih & Bersih \\
\hline \multirow{3}{*}{ HARI 7} & Tdk ada endapan & Tdk ada endapan & Tdk ada endapan & Tdk ada endapan \\
\hline & Tdk ada pemisahan & Tdk ada pemisahan & Tdk ada pemisahan & Tdk ada pemisahan \\
\hline & Bersih & Bersih & Bersih & Bersih \\
\hline
\end{tabular}




\begin{tabular}{|c|c|c|}
\hline \multirow[t]{2}{*}{ PENGAMATAN } & \multicolumn{2}{|c|}{ 10. CAMPURAN E } \\
\hline & SUHU KAMAR & $65^{\circ} \mathrm{C}$ \\
\hline \multirow{3}{*}{ HARI 1} & Tdk ada endapan & Tdk ada endapan \\
\hline & Tdk ada pemisahan & Tdk ada pemisahan \\
\hline & Bersih & Bersih \\
\hline \multirow{3}{*}{ HARI 2} & Tdk ada endapan & Tdk ada endapan \\
\hline & Tdk ada pemisahan & Tdk ada pemisahan \\
\hline & Bersih & Bersih \\
\hline \multirow{3}{*}{ HARI 3} & Tdk ada endapan & Tdk ada endapan \\
\hline & Tdk ada pemisahan & Tdk ada pemisahan \\
\hline & Bersih & Bersih \\
\hline \multirow{3}{*}{ HARI 4} & Tdk ada endapan & Tdk ada endapan \\
\hline & Tdk ada pemisahan & Tdk ada pemisahan \\
\hline & Bersih & Bersih \\
\hline \multirow{3}{*}{ HARI 5} & Tdk ada endapan & Tdk ada endapan \\
\hline & Tdk ada pemisahan & Tdk ada pemisahan \\
\hline & Bersih & Bersih \\
\hline \multirow{3}{*}{ HARI 6} & Tdk ada endapan & Tdk ada endapan \\
\hline & Tdk ada pemisahan & Tdk ada pemisahan \\
\hline & Bersih & Bersih \\
\hline \multirow{3}{*}{ HARI 7} & Tdk ada endapan & Tdk ada endapan \\
\hline & Tdk ada pemisahan & Tdk ada pemisahan \\
\hline & Bersih & Bersih \\
\hline
\end{tabular}

Tabel 3. Data hasil pengamatan kompatibilitas campuran oli mesin mineral dan mineral (Multigrade)

\begin{tabular}{|c|c|c|c|c|}
\hline \multirow[t]{2}{*}{ PENGAMATAN } & \multicolumn{2}{|c|}{ 6. CAMPURAN A } & \multicolumn{2}{|c|}{ 7. CAMPURAN B } \\
\hline & SUHU KAMAR & $65^{\circ} \mathrm{C}$ & SUHU KAMAR & $65^{\circ} \mathrm{C}$ \\
\hline & Tdk ada endapan & Tdk ada endapan & Tdk ada endapan & Tdk ada endapan \\
\hline \multirow[t]{3}{*}{ HARI 1} & Tdk ada pemisahan & Tdk ada pemisahan & Tdk ada pemisahan & Tdk ada pemisahan \\
\hline & Bersih & Bersih & Bersih & Bersih \\
\hline & Tdk ada endapan & Tdk ada endapan & Tdk ada endapan & Tdk ada endapan \\
\hline \multirow[t]{3}{*}{ HARI 2} & Tdk ada pemisahan & Tdk ada pemisahan & Tdk ada pemisahan & Tdk ada pemisahan \\
\hline & Bersih & Bersih & Bersih & Bersih \\
\hline & Tdk ada endapan & Tdk ada endapan & Tdk ada endapan & Tdk ada endapan \\
\hline \multirow[t]{3}{*}{ HARI 3} & Tdk ada pemisahan & Tdk ada pemisahan & Tdk ada pemisahan & Tdk ada pemisahan \\
\hline & Bersih & Bersih & Bersih & Bersih \\
\hline & Tdk ada endapan & Tdk ada endapan & Tdk ada endapan & Tdk ada endapan \\
\hline \multirow[t]{3}{*}{ HARI 4} & Tdk ada pemisahan & Tdk ada pemisahan & Tdk ada pemisahan & Tdk ada pemisahan \\
\hline & Bersih & Bersih & Bersih & Bersih \\
\hline & Tdk ada endapan & Tdk ada endapan & Tdk ada endapan & Tdk ada endapan \\
\hline \multirow[t]{3}{*}{ HARI 5} & Tdk ada pemisahan & Tdk ada pemisahan & Tdk ada pemisahan & Tdk ada pemisahan \\
\hline & Bersih & Bersih & Bersih & Bersih \\
\hline & Tdk ada endapan & Tdk ada endapan & Tdk ada endapan & Tdk ada endapan \\
\hline \multirow[t]{3}{*}{ HARI 6} & Tdk ada pemisahan & Tdk ada pemisahan & Tdk ada pemisahan & Tdk ada pemisahan \\
\hline & Bersih & Bersih & Bersih & Bersih \\
\hline & Tdk ada endapan & Tdk ada endapan & Tdk ada endapan & Tdk ada endapan \\
\hline \multirow[t]{2}{*}{ HARI 7} & Tdk ada pemisahan & Tdk ada pemisahan & Tdk ada pemisahan & Tdk ada pemisahan \\
\hline & Bersih & Bersih & Bersih & Bersih \\
\hline
\end{tabular}




\begin{tabular}{lllll}
\hline PENGAMATAN & \multicolumn{2}{c}{ 8. CAMPURAN C } & \multicolumn{2}{c}{ 9. CAMPURAN D } \\
\cline { 2 - 5 } & SUHU KAMAR & 65C & SUHU KAMAR & 65C \\
\hline \multirow{3}{*}{ HARI 1 } & Tdk ada endapan & Tdk ada endapan & Tdk ada endapan & Tdk ada endapan \\
\cline { 2 - 5 } & Tdk ada pemisahan & Tdk ada pemisahan & Tdk ada pemisahan & Tdk ada pemisahan \\
\cline { 2 - 5 } & Bersih & Bersih & Bersih & Bersih \\
\hline \multirow{3}{*}{ HARI 2 } & Tdk ada endapan & Tdk ada endapan & Tdk ada endapan & Tdk ada endapan \\
\cline { 2 - 5 } & Tdk ada pemisahan & Tdk ada pemisahan & Tdk ada pemisahan & Tdk ada pemisahan \\
\cline { 2 - 5 } & Bersih & Bersih & Bersih & Bersih \\
\hline \multirow{3}{*}{ HARI 3 3} & Tdk ada endapan & Tdk ada endapan & Tdk ada endapan & Tdk ada endapan \\
\cline { 2 - 5 } & Tdk ada pemisahan & Tdk ada pemisahan & Tdk ada pemisahan & Tdk ada pemisahan \\
\cline { 2 - 5 } & Bersih & Bersih & Bersih & Bersih \\
\hline \multirow{3}{*}{ HARI 4 } & Tdk ada endapan & Tdk ada endapan & Tdk ada endapan & Tdk ada endapan \\
\cline { 2 - 5 } & Tdk ada pemisahan & Tdk ada pemisahan & Tdk ada pemisahan & Tdk ada pemisahan \\
\cline { 2 - 5 } & Bersih & Bersih & Bersih & Bersih \\
\hline \multirow{3}{*}{ HARI 5 } & Tdk ada endapan & Tdk ada endapan & Tdk ada endapan & Tdk ada endapan \\
\cline { 2 - 5 } & Tdk ada pemisahan & Tdk ada pemisahan & Tdk ada pemisahan & Tdk ada pemisahan \\
\cline { 2 - 5 } & Bersih & Bersih & Bersih & Bersih \\
\hline \multirow{3}{*}{ HARI 6 6} & Tdk ada endapan & Tdk ada endapan & Tdk ada endapan & Tdk ada endapan \\
\cline { 2 - 5 } & Tdk ada pemisahan & Tdk ada pemisahan & Tdk ada pemisahan & Tdk ada pemisahan \\
\cline { 2 - 5 } & Bersih & Bersih & Bersih & Bersih \\
\hline \multirow{2}{*}{ HARI 7 } & Tdk ada endapan & Tdk ada endapan & Tdk ada endapan & Tdk ada endapan \\
\cline { 2 - 5 } & Tdk ada pemisahan & Tdk ada pemisahan & Tdk ada pemisahan & Tdk ada pemisahan \\
\cline { 2 - 5 } & Bersih & Bersih & Bersih & Bersih \\
\hline
\end{tabular}

\begin{tabular}{rll}
\hline PENGAMATAN & \multicolumn{2}{c}{ 10. CAMPURAN E } \\
\cline { 2 - 3 } & SUHU KAMAR & 65ㅇ \\
\hline \multirow{3}{*}{ HARI 1 } & Tdk ada endapan & Tdk ada endapan \\
\cline { 2 - 3 } & Tdk ada pemisahan & Tdk ada pemisahan \\
\cline { 2 - 3 } HARI 2 & Bersih & Bersih \\
\cline { 2 - 3 } & Tdk ada endapan & Tdk ada endapan \\
\cline { 2 - 3 } & Tdk ada pemisahan & Tdk ada pemisahan \\
\hline \multirow{3}{*}{ HARI 3 } & Tdk ada endapan & Bersih \\
\cline { 2 - 3 } & Tdk ada pemisahan & Tdk ada endapan \\
\cline { 2 - 3 } & Bersih & Bersih \\
\hline \multirow{3}{*}{ HARI 4 } & Tdk ada endapan & Tdk ada endapan \\
\cline { 2 - 3 } & Tdk ada pemisahan & Tdk ada pemisahan \\
\cline { 2 - 3 } & Bersih & Bersih \\
\hline \multirow{3}{*}{ HARI 5 } & Tdk ada endapan & Tdk ada endapan \\
\cline { 2 - 3 } & Tdk ada pemisahan & Tdk ada pemisahan \\
\cline { 2 - 3 } & Bersih & Bersih \\
\hline \multirow{3}{*}{ HARI 6 } & Tdk ada endapan & Tdk ada endapan \\
\cline { 2 - 3 } & Tdk ada pemisahan & Tdk ada pemisahan \\
\cline { 2 - 3 } & Bersih & Bersih \\
\hline \multirow{2}{*}{ HARI 7 } & Tdk ada endapan & Tdk ada endapan \\
\cline { 2 - 3 } & Tdk ada pemisahan & Tdk ada pemisahan \\
\cline { 2 - 3 } & Bersih & Bersih \\
\hline
\end{tabular}


Tabel 4. Data hasil pengamatan kompatibilitas campuran oli mesin mineral dan Sintetik (SAE 40)

\begin{tabular}{|c|c|c|c|c|}
\hline \multirow[t]{2}{*}{ PENGAMATAN } & \multicolumn{2}{|c|}{ 11. CAMPURAN A } & \multicolumn{2}{|c|}{ 12. CAMPURAN B } \\
\hline & SUHU KAMAR & $65^{\circ} \mathrm{C}$ & SUHU KAMAR & $65^{\circ} \mathrm{C}$ \\
\hline \multirow{3}{*}{ HARI 1} & Tdk ada endapan & Tdk ada endapan & Tdk ada endapan & Tdk ada endapan \\
\hline & Tdk ada pemisahan & Tdk ada pemisahan & Tdk ada pemisahan & Tdk ada pemisahan \\
\hline & Bersih & Bersih & Bersih & Bersih \\
\hline \multirow{3}{*}{ HARI 2} & Tdk ada endapan & Tdk ada endapan & Tdk ada endapan & Tdk ada endapan \\
\hline & Tdk ada pemisahan & Tdk ada pemisahan & Tdk ada pemisahan & Tdk ada pemisahan \\
\hline & Bersih & Bersih & Bersih & Bersih \\
\hline \multirow{3}{*}{ HARI 3} & Tdk ada endapan & Tdk ada endapan & Tdk ada endapan & Tdk ada endapan \\
\hline & Tdk ada pemisahan & Tdk ada pemisahan & Tdk ada pemisahan & Tdk ada pemisahan \\
\hline & Bersih & Bersih & Bersih & Bersih \\
\hline \multirow{3}{*}{ HARI 4} & Tdk ada endapan & Tdk ada endapan & Tdk ada endapan & Tdk ada endapan \\
\hline & Tdk ada pemisahan & Tdk ada pemisahan & Tdk ada pemisahan & Tdk ada pemisahan \\
\hline & Bersih & Bersih & Bersih & Bersih \\
\hline \multirow{3}{*}{ HARI 5} & Tdk ada endapan & Tdk ada endapan & Tdk ada endapan & Tdk ada endapan \\
\hline & Tdk ada pemisahan & Tdk ada pemisahan & Tdk ada pemisahan & Tdk ada pemisahan \\
\hline & Bersih & Bersih & Bersih & Bersih \\
\hline \multirow{3}{*}{ HARI 6} & Tdk ada endapan & Tdk ada endapan & Tdk ada endapan & Tdk ada endapan \\
\hline & Tdk ada pemisahan & Tdk ada pemisahan & Tdk ada pemisahan & Tdk ada pemisahan \\
\hline & Bersih & Bersih & Bersih & Bersih \\
\hline \multirow{3}{*}{ HARI 7} & Tdk ada endapan & Tdk ada endapan & Tdk ada endapan & Tdk ada endapan \\
\hline & Tdk ada pemisahan & Tdk ada pemisahan & Tdk ada pemisahan & Tdk ada pemisahan \\
\hline & Bersih & Bersih & Bersih & Bersih \\
\hline
\end{tabular}

\begin{tabular}{|c|c|c|c|c|}
\hline \multirow[t]{2}{*}{ PENGAMATAN } & \multicolumn{2}{|c|}{ 13. CAMPURAN C } & \multicolumn{2}{|c|}{ 14. CAMPURAN D } \\
\hline & SUHU KAMAR & $65^{\circ} \mathrm{C}$ & SUHU KAMAR & $65^{\circ} \mathrm{C}$ \\
\hline \multirow{3}{*}{ HARI 1} & Tdk ada endapan & Tdk ada endapan & Tdk ada endapan & Tdk ada endapan \\
\hline & Tdk ada pemisahan & Tdk ada pemisahan & Tdk ada pemisahan & Tdk ada pemisahan \\
\hline & Bersih & Bersih & Bersih & Bersih \\
\hline \multirow{3}{*}{ HARI 2} & Tdk ada endapan & Tdk ada endapan & Tdk ada endapan & Tdk ada endapan \\
\hline & Tdk ada pemisahan & Tdk ada pemisahan & Tdk ada pemisahan & Tdk ada pemisahan \\
\hline & Bersih & Bersih & Bersih & Bersih \\
\hline \multirow{3}{*}{ HARI 3} & Tdk ada endapan & Tdk ada endapan & Tdk ada endapan & Tdk ada endapan \\
\hline & Tdk ada pemisahan & Tdk ada pemisahan & Tdk ada pemisahan & Tdk ada pemisahan \\
\hline & Bersih & Bersih & Bersih & Bersih \\
\hline \multirow{3}{*}{ HARI 4} & Tdk ada endapan & Tdk ada endapan & Tdk ada endapan & Tdk ada endapan \\
\hline & Tdk ada pemisahan & Tdk ada pemisahan & Tdk ada pemisahan & Tdk ada pemisahan \\
\hline & Bersih & Bersih & Bersih & Bersih \\
\hline \multirow{3}{*}{ HARI 5} & Tdk ada endapan & Tdk ada endapan & Tdk ada endapan & Tdk ada endapan \\
\hline & Tdk ada pemisahan & Tdk ada pemisahan & Tdk ada pemisahan & Tdk ada pemisahan \\
\hline & Bersih & Bersih & Bersih & Bersih \\
\hline \multirow{3}{*}{ HARI 6} & Tdk ada endapan & Ada endapan & Tdk ada endapan & Ada endapan \\
\hline & Tdk ada pemisahan & Tdk ada pemisahan & Tdk ada pemisahan & Tdk ada pemisahan \\
\hline & Bersih & Bersih & Bersih & Bersih \\
\hline \multirow{3}{*}{ HARI 7} & Tdk ada endapan & Ada endapan & Tdk ada endapan & Ada endapan \\
\hline & Tdk ada pemisahan & Tdk ada pemisahan & Tdk ada pemisahan & Tdk ada pemisahan \\
\hline & Bersih & Bersih & Bersih & Bersih \\
\hline
\end{tabular}




\begin{tabular}{|c|c|c|}
\hline \multirow[t]{2}{*}{ PENGAMATAN } & \multicolumn{2}{|c|}{ 15. CAMPURAN E } \\
\hline & SUHU KAMAR & $65^{\circ} \mathrm{C}$ \\
\hline \multirow{3}{*}{ HARI 1} & Tdk ada endapan & Tdk ada endapan \\
\hline & Tdk ada pemisahan & Tdk ada pemisahan \\
\hline & Bersih & Bersih \\
\hline \multirow{3}{*}{ HARI 2} & Tdk ada endapan & Tdk ada endapan \\
\hline & Tdk ada pemisahan & Tdk ada pemisahan \\
\hline & Bersih & Bersih \\
\hline \multirow{3}{*}{ HARI 3} & Tdk ada endapan & Tdk ada endapan \\
\hline & Tdk ada pemisahan & Tdk ada pemisahan \\
\hline & Bersih & Bersih \\
\hline \multirow{3}{*}{ HARI 4} & Tdk ada endapan & Tdk ada endapan \\
\hline & Tdk ada pemisahan & Tdk ada pemisahan \\
\hline & Bersih & Bersih \\
\hline \multirow{3}{*}{ HARI 5} & Tdk ada endapan & Tdk ada endapan \\
\hline & Tdk ada pemisahan & Tdk ada pemisahan \\
\hline & Bersih & Bersih \\
\hline \multirow{3}{*}{ HARI 6} & Tdk ada endapan & Ada endapan \\
\hline & Tdk ada pemisahan & Tdk ada pemisahan \\
\hline & Bersih & Bersih \\
\hline \multirow{3}{*}{ HARI 7} & Tdk ada endapan & Ada endapan \\
\hline & Tdk ada pemisahan & Tdk ada pemisahan \\
\hline & Bersih & Bersih \\
\hline
\end{tabular}

Tabel 5. Data hasil pengamatan kompatibilitas campuran oli hidrolik mineral dan mineral (ISO VG 46)

\begin{tabular}{|c|c|c|c|c|}
\hline \multirow[t]{2}{*}{ PENGAMATAN } & \multicolumn{2}{|c|}{ 16. CAMPURAN A } & \multicolumn{2}{|c|}{ 17. CAMPURAN B } \\
\hline & SUHU KAMAR & $65^{\circ} \mathrm{C}$ & SUHU KAMAR & $65^{\circ} \mathrm{C}$ \\
\hline \multirow{3}{*}{ HARI 1} & Tdk ada endapan & Tdk ada endapan & Tdk ada endapan & Tdk ada endapan \\
\hline & Tdk ada pemisahan & Tdk ada pemisahan & Tdk ada pemisahan & Tdk ada pemisahan \\
\hline & Bersih & Bersih & Bersih & Bersih \\
\hline \multirow{3}{*}{ HARI 2} & Tdk ada endapan & Tdk ada endapan & Tdk ada endapan & Tdk ada endapan \\
\hline & Tdk ada pemisahan & Tdk ada pemisahan & Tdk ada pemisahan & Tdk ada pemisahan \\
\hline & Bersih & Bersih & Bersih & Bersih \\
\hline \multirow{3}{*}{ HARI 3} & Tdk ada endapan & Tdk ada endapan & Tdk ada endapan & Tdk ada endapan \\
\hline & Tdk ada pemisahan & Tdk ada pemisahan & Tdk ada pemisahan & Tdk ada pemisahan \\
\hline & Bersih & Bersih & Bersih & Bersih \\
\hline \multirow{3}{*}{ HARI 4} & Tdk ada endapan & Tdk ada endapan & Tdk ada endapan & Tdk ada endapan \\
\hline & Tdk ada pemisahan & Tdk ada pemisahan & Tdk ada pemisahan & Tdk ada pemisahan \\
\hline & Bersih & Bersih & Bersih & Bersih \\
\hline \multirow{3}{*}{ HARI 5} & Tdk ada endapan & Tdk ada endapan & Tdk ada endapan & Tdk ada endapan \\
\hline & Tdk ada pemisahan & Tdk ada pemisahan & Tdk ada pemisahan & Tdk ada pemisahan \\
\hline & Bersih & Bersih & Bersih & Bersih \\
\hline \multirow{3}{*}{ HARI 6} & Tdk ada endapan & Tdk ada endapan & Tdk ada endapan & Tdk ada endapan \\
\hline & Tdk ada pemisahan & Tdk ada pemisahan & Tdk ada pemisahan & Tdk ada pemisahan \\
\hline & Bersih & Bersih & Bersih & Bersih \\
\hline \multirow{3}{*}{ HARI 7} & Tdk ada endapan & Tdk ada endapan & Tdk ada endapan & Tdk ada endapan \\
\hline & Tdk ada pemisahan & Tdk ada pemisahan & Tdk ada pemisahan & Tdk ada pemisahan \\
\hline & Bersih & Bersih & Bersih & Bersih \\
\hline
\end{tabular}




\begin{tabular}{lllll}
\hline PENGAMATAN & \multicolumn{2}{c}{ 18. CAMPURAN C } & \multicolumn{2}{c}{ 19. CAMPURAN D } \\
\cline { 2 - 5 } & SUHU KAMAR & 65ㅇ & SUHU KAMAR & 65ㄷ \\
\hline \multirow{3}{*}{ HARI 1 } & Tdk ada endapan & Tdk ada endapan & Tdk ada endapan & Tdk ada endapan \\
\cline { 2 - 5 } & Tdk ada pemisahan & Tdk ada pemisahan & Tdk ada pemisahan & Tdk ada pemisahan \\
\cline { 2 - 5 } & Bersih & Bersih & Bersih & Bersih \\
\hline \multirow{3}{*}{ HARI 2 } & Tdk ada endapan & Tdk ada endapan & Tdk ada endapan & Tdk ada endapan \\
\cline { 2 - 5 } & Tdk ada pemisahan & Tdk ada pemisahan & Tdk ada pemisahan & Tdk ada pemisahan \\
\cline { 2 - 5 } & Bersih & Bersih & Bersih & Bersih \\
\hline \multirow{3}{*}{ HARI 3 } & Tdk ada endapan & Tdk ada endapan & Tdk ada endapan & Tdk ada endapan \\
\cline { 2 - 5 } & Tdk ada pemisahan & Tdk ada pemisahan & Tdk ada pemisahan & Tdk ada pemisahan \\
\cline { 2 - 5 } & Bersih & Bersih & Bersih & Bersih \\
\hline \multirow{3}{*}{ HARI 4 } & Tdk ada endapan & Tdk ada endapan & Tdk ada endapan & Tdk ada endapan \\
\cline { 2 - 5 } & Tdk ada pemisahan & Tdk ada pemisahan & Tdk ada pemisahan & Tdk ada pemisahan \\
\cline { 2 - 5 } & Bersih & Bersih & Bersih & Bersih \\
\hline \multirow{3}{*}{ HARI 5 } & Tdk ada endapan & Tdk ada endapan & Tdk ada endapan & Tdk ada endapan \\
\cline { 2 - 5 } & Tdk ada pemisahan & Tdk ada pemisahan & Tdk ada pemisahan & Tdk ada pemisahan \\
\cline { 2 - 5 } & Bersih & Bersih & Bersih & Bersih \\
\hline \multirow{3}{*}{ HARI 6 } & Tdk ada endapan & Tdk ada endapan & Tdk ada endapan & Tdk ada endapan \\
\cline { 2 - 5 } & Tdk ada pemisahan & Tdk ada pemisahan & Tdk ada pemisahan & Tdk ada pemisahan \\
\cline { 2 - 5 } & Bersih & Bersih & Bersih & Bersih \\
\hline \multirow{3}{*}{ HARI 7 } & Tdk ada endapan & Tdk ada endapan & Tdk ada endapan & Tdk ada endapan \\
\cline { 2 - 5 } & Tdk ada pemisahan & Tdk ada pemisahan & Tdk ada pemisahan & Tdk ada pemisahan \\
\cline { 2 - 5 } & Bersih & Bersih & Bersih & Bersih \\
\hline
\end{tabular}

\begin{tabular}{lll}
\hline PENGAMATAN & \multicolumn{2}{c}{ 25. CAMPURAN E } \\
\cline { 2 - 3 } & SUHU KAMAR & 65ㅇ \\
\hline \multirow{3}{*}{ HARI 1 } & Tdk ada endapan & Tdk ada endapan \\
\cline { 2 - 3 } & Tdk ada pemisahan & Tdk ada pemisahan \\
\cline { 2 - 3 } HARI 2 & Bersih & Bersih \\
\cline { 2 - 3 } & Tdk ada endapan & Tdk ada endapan \\
\cline { 2 - 3 } & Tdk ada pemisahan & Tdk ada pemisahan \\
\hline \multirow{3}{*}{ HARI 3 } & Tdk ada endapan & Bersih \\
\cline { 2 - 3 } & Tdk ada pemisahan & Tdk ada endapan \\
\cline { 2 - 3 } & Bersih & Bersih \\
\hline \multirow{3}{*}{ HARI 4 } & Tdk ada endapan & Tdk ada endapan \\
\cline { 2 - 3 } & Tdk ada pemisahan & Tdk ada pemisahan \\
\cline { 2 - 3 } & Bersih & Bersih \\
\hline \multirow{3}{*}{ HARI 5 } & Tdk ada endapan & Tdk ada endapan \\
\cline { 2 - 3 } & Tdk ada pemisahan & Tdk ada pemisahan \\
\cline { 2 - 3 } & Bersih & Bersih \\
\hline \multirow{2}{*}{ HARI 6 } & Tdk ada endapan & Tdk ada endapan \\
\cline { 2 - 3 } & Tdk ada pemisahan & Tdk ada pemisahan \\
\cline { 2 - 3 } & Bersih & Bersih \\
\hline \multirow{2}{*}{ HARI 7 } & Tdk ada endapan & Tdk ada endapan \\
\cline { 2 - 3 } & Tdk ada pemisahan & Tdk ada pemisahan \\
\cline { 2 - 3 } & Bersih & Bersih \\
\hline
\end{tabular}


Tabel 6. Data hasil pengamatan kompatibilitas campuran oli hidrolik mineral dan sintetik (ISO VG 32)

\begin{tabular}{|c|c|c|c|c|}
\hline \multirow[t]{2}{*}{ PENGAMATAN } & \multicolumn{2}{|c|}{ 21. CAMPURAN A } & \multicolumn{2}{|c|}{ 22. CAMPURAN B } \\
\hline & SUHU KAMAR & $65^{\circ} \mathrm{C}$ & SUHU KAMAR & $65^{\circ} \mathrm{C}$ \\
\hline \multirow{3}{*}{ HARI 1} & Tdk ada endapan & Tdk ada endapan & Tdk ada endapan & Tdk ada endapan \\
\hline & Tdk ada pemisahan & Tdk ada pemisahan & Tdk ada pemisahan & Tdk ada pemisahan \\
\hline & Bersih & Bersih & Bersih & Bersih \\
\hline \multirow{3}{*}{ HARI 2} & Tdk ada endapan & Tdk ada endapan & Tdk ada endapan & Tdk ada endapan \\
\hline & Tdk ada pemisahan & Tdk ada pemisahan & Tdk ada pemisahan & Tdk ada pemisahan \\
\hline & Bersih & Bersih & Bersih & Bersih \\
\hline \multirow{3}{*}{ HARI 3} & Tdk ada endapan & Tdk ada endapan & Tdk ada endapan & Tdk ada endapan \\
\hline & Tdk ada pemisahan & Tdk ada pemisahan & Tdk ada pemisahan & Tdk ada pemisahan \\
\hline & Bersih & Bersih & Bersih & Bersih \\
\hline \multirow{3}{*}{ HARI 4} & Tdk ada endapan & Tdk ada endapan & Tdk ada endapan & Tdk ada endapan \\
\hline & Tdk ada pemisahan & Tdk ada pemisahan & Tdk ada pemisahan & Tdk ada pemisahan \\
\hline & Bersih & Bersih & Bersih & Bersih \\
\hline \multirow{3}{*}{ HARI 5} & Tdk ada endapan & Tdk ada endapan & Tdk ada endapan & Tdk ada endapan \\
\hline & Tdk ada pemisahan & Tdk ada pemisahan & Tdk ada pemisahan & Tdk ada pemisahan \\
\hline & Bersih & Bersih & Bersih & Bersih \\
\hline \multirow{3}{*}{ HARI 6} & Tdk ada endapan & Tdk ada endapan & Tdk ada endapan & Tdk ada endapan \\
\hline & Tdk ada pemisahan & Tdk ada pemisahan & Tdk ada pemisahan & Tdk ada pemisahan \\
\hline & Bersih & Bersih & Bersih & Bersih \\
\hline \multirow{3}{*}{ HARI 7} & Tdk ada endapan & Tdk ada endapan & Tdk ada endapan & Tdk ada endapan \\
\hline & Tdk ada pemisahan & Tdk ada pemisahan & Tdk ada pemisahan & Tdk ada pemisahan \\
\hline & Bersih & Bersih & Bersih & Bersih \\
\hline
\end{tabular}

\begin{tabular}{cllll}
\hline PENGAMATAN & \multicolumn{2}{c}{ 23. CAMPURAN C } & \multicolumn{2}{c}{ 24. CAMPURAN D } \\
\cline { 2 - 5 } & SUHU KAMAR & 65ㄷ & SUHU KAMAR & 65ㅇ \\
\hline \multirow{3}{*}{ HARI 1 } & Tdk ada endapan & Tdk ada endapan & Tdk ada endapan & Tdk ada endapan \\
\cline { 2 - 5 } & Tdk ada pemisahan & Tdk ada pemisahan & Tdk ada pemisahan & Tdk ada pemisahan \\
\cline { 2 - 5 } & Bersih & Bersih & Bersih & Bersih \\
\hline \multirow{3}{*}{ HARI 2 } & Tdk ada endapan & Tdk ada endapan & Tdk ada endapan & Tdk ada endapan \\
\cline { 2 - 5 } & Tdk ada pemisahan & Tdk ada pemisahan & Tdk ada pemisahan & Tdk ada pemisahan \\
\cline { 2 - 5 } & Bersih & Bersih & Bersih & Bersih \\
\hline \multirow{3}{*}{ HARI 3 } & Tdk ada endapan & Tdk ada endapan & Tdk ada endapan & Tdk ada endapan \\
\cline { 2 - 5 } & Tdk ada pemisahan & Tdk ada pemisahan & Tdk ada pemisahan & Tdk ada pemisahan \\
\cline { 2 - 5 } & Bersih & Bersih & Bersih & Bersih \\
\hline \multirow{3}{*}{ HARI 4 } & Tdk ada endapan & Tdk ada endapan & Tdk ada endapan & Tdk ada endapan \\
\cline { 2 - 5 } & Tdk ada pemisahan & Tdk ada pemisahan & Tdk ada pemisahan & Tdk ada pemisahan \\
\cline { 2 - 5 } & Bersih & Bersih & Bersih & Bersih \\
\hline \multirow{3}{*}{ HARI 5 } & Tdk ada endapan & Tdk ada endapan & Tdk ada endapan & Tdk ada endapan \\
\cline { 2 - 5 } & Tdk ada pemisahan & Tdk ada pemisahan & Tdk ada pemisahan & Tdk ada pemisahan \\
\cline { 2 - 5 } & Bersih & Bersih & Bersih & Bersih \\
\hline \multirow{3}{*}{ HARI 6 } & Tdk ada endapan & Tdk ada endapan & Tdk ada endapan & Tdk ada endapan \\
\cline { 2 - 5 } & Tdk ada pemisahan & Tdk ada pemisahan & Tdk ada pemisahan & Tdk ada pemisahan \\
\cline { 2 - 5 } & Bersih & Bersih & Bersih & Bersih \\
\hline \multirow{2}{*}{ HARI 7 } & Tdk ada endapan & Tdk ada endapan & Tdk ada endapan & Tdk ada endapan \\
\cline { 2 - 5 } & Tdk ada pemisahan & Tdk ada pemisahan & Tdk ada pemisahan & Tdk ada pemisahan \\
\cline { 2 - 5 } & Bersih & Bersih & Bersih & Bersih \\
\hline
\end{tabular}




\begin{tabular}{|c|c|c|}
\hline \multirow[t]{2}{*}{ PENGAMATAN } & \multicolumn{2}{|c|}{ 25. CAMPURAN E } \\
\hline & SUHU KAMAR & $65^{\circ} \mathrm{C}$ \\
\hline \multirow{3}{*}{ HARI 1} & Tdk ada endapan & Tdk ada endapan \\
\hline & Tdk ada pemisahan & Tdk ada pemisahan \\
\hline & Bersih & Bersih \\
\hline \multirow{3}{*}{ HARI 2} & Tdk ada endapan & Tdk ada endapan \\
\hline & Tdk ada pemisahan & Tdk ada pemisahan \\
\hline & Bersih & Bersih \\
\hline \multirow{3}{*}{ HARI 3} & Tdk ada endapan & Tdk ada endapan \\
\hline & Tdk ada pemisahan & Tdk ada pemisahan \\
\hline & Bersih & Bersih \\
\hline \multirow{3}{*}{ HARI 4} & Tdk ada endapan & Tdk ada endapan \\
\hline & Tdk ada pemisahan & Tdk ada pemisahan \\
\hline & Bersih & Bersih \\
\hline \multirow{3}{*}{ HARI 5} & Tdk ada endapan & Tdk ada endapan \\
\hline & Tdk ada pemisahan & Tdk ada pemisahan \\
\hline & Bersih & Bersih \\
\hline \multirow{3}{*}{ HARI 6} & Tdk ada endapan & Tdk ada endapan \\
\hline & Tdk ada pemisahan & Tdk ada pemisahan \\
\hline & Bersih & Bersih \\
\hline \multirow{3}{*}{ HARI 7} & Tdk ada endapan & Tdk ada endapan \\
\hline & Tdk ada pemisahan & Tdk ada pemisahan \\
\hline & Bersih & Bersih \\
\hline
\end{tabular}

\section{PEMBAHASAN}

\section{Analisis kompatibilitas campuran pelumas Mesin Industri}

Pelumas mesin adalah pelumas yang paling banyak digunakan pada kendaraan angkutan diindustri-industri. Berdasarkan pengamatan yang sering ditemukan dilapangan, pelumas jenis ini paling sering dicampur dengan merek pelumas yang berbeda dengan jenis yang sama. Dikarenakan rutinitas kegiatan yang cukup tinggi menyebabkan pemakai tidak terlalu memperhatikan merek pada jenis pelumas ini. Pelumas mesin terdiri dari dua macam kekentalan yaitu Monograde dan Multigrade. Prlumas monograde adalah pelumas dengan kekentalan tunggal misalnya SAE 10W, SAE 40, SAE 50, dll. Sedangkan pelumas multigrade adalah pelumas yang memiliki kekentalan ganda seperti SAE 10W-40, SAE 20W-50, dll. Pada penelitian ini sampel pelumas diambil dari dua merek yang berbeda yang banyak dijual dipasaran. Untuk pelums monograde diambil sampel dengan kekentalan SAE 40, dan untuk pelumas multigrade sampel yang diamati adalah kekentalan dengan SAE 80W-90. Sampel masing-masing dibuat dengan 5 komposisi campuran berbeda yaitu 0:100, 20:80, 50:50, 80:100, 100:0. Masing-masing sampel dibuat $200 \mathrm{mg}$ dan dibagi 2 . Sampel yang pertama ditempatkan di ruangan dengan suhu kamar dan sampel kedua ditempatkan didalam oven dengan suhu $65^{\circ} \mathrm{C}$ kemudian dilakukan pengamatan selama 7 hari.

Dari hasil pengamatan yang dapat dilihat pada tabel 4.2 tidak ditemukan adanya endapan dan tidak terjadi pemisahan pada semua komposisi campuran. Sampel terlihat bersih. Untuk sampel dengan jenis campuran pelumas dengan SAE 40 dari bahan dasar mineral dicampur mineral menunjukkan bahwa pelumas ini kompatibel jika dilakukan campuran dengan 5 komposisi berbeda. Pelumas jenis ini tidak menimbulkan masalah pada mesin jika dilakukan pencampuran. Hal ini menunjukkan bahwa ada kesamaan aditif dan bahan dasar yang sama pada kedua merek pelumas yang dijadikan sampel pengujian.

Dari hasil pengamatan yang dapat dilihat pada tabel 4.3 sampel diambil dari 
kekentalan multigrade yaitu SAE 80W-90 dari dua merk berbeda dan bahan dasar yang sama. Hasil pengamatan selama 7 hari menunjukkan sampel pelumas ini kompatibel dan dapat dilakukan pencampuran. Pada sampel tidak ditemukan endapan dan pemisahan dan terlihat bersih untuk semua komposisi pencampuran. Kedua jenis pelumas ini terbuat dari bahan dasar dan aditif yang sejenis.

Dari hasil pengamatan yang dapat dilihat pada tabel 4.3, sampel pelumas yang diambil adalah pelumas monograde dengan kekentalan SAE 40 dari bahan dasar dan merk yang berbeda. Dari pengamatan dengan komposisi 0:100 (campuran A), 20:80 (campuran B) dan 100:20 (campuran E) tidak ditemukan endapan dan tidak terjadi pemisahan. Campuran pelumas terlihat bersih selama pengamatan 7 hari pada kedua suhu. Untuk sampel dengan komposisi 50:50 (campuran C) dan 80:20 (campuran D) sampai dengan hari ke-5 pelumas masih kompatibel. Setelah hari ke-6 dan ke-7 ditemukan adanya endapan pada sampel yang ditempatkan pada suhu $65^{\circ} \mathrm{C}$. Hal ini menunjukkan bahwa terdapat aditif yang berbeda yang ditambahkan pada saat pembuatan pelumas sehingga pelumas tidak kompatibel. Pelumas dengan jenis ini tidak disarankan untuk dicampur karena pada saat digunakan pada mesin dapat menyebabkan kegagalan mesin.

\section{Analisis kompatibilitas campuran campuran pelumas hidrolik Industri}

Pelumas hidrolik adalah pelumas yang digunakan pada mesin-mesin hidrolik. Mesin hidrolik sangat banyak digunakan pada industry seperti industri pembuatan sepatu, plastik, dan masih banyak lagi. Oli hidrolik juga digunakan pada alat-alat berat didaerah pertambangan seperti excavator. Mesin-mesin hidrolik biasanya mempunyai kapasitas tangki yang sangat besar sehingga membutuhkan pelumas yang cukup banyak bisa sampai 20-30 drum isi 200 liter. Hal ini dapat menimbulkan kendala di lapangan dikarenakan biaya yang harus dikeluarkan sangat tinggi apabila harus mengganti pelumas secara keseluruhan. Operator mesin dilapangan biasanya hanya melakukan penambahan apabila pelumas berkurang karena penguapan pada saat digunakan. Adanya efisiensi biaya yang ditawarkan oleh produsen pelumas juga biasanya menyebabkan pelumas dilakukan pencampuran. Pada penelitian ini dilakukan pengamatan terhadap dua jenis sampel dengan merek berbeda, kekentalan berbeda tetapi dari jenis bahan dasar yang sama. Pelumas dengan kekentalan ini paling banyak digunakan pada mesin-mesin industri. Mengingat harga pelumas ini cukup tinggi terutama jenis sintetik dan pelumas juga tidak dijual eceran menyebabkan penelitian ini hanya dilakukan pada dua sampel saja. Sampel pelumas yang dipilih adalah dengan kekentalan ISO VG 32 dan ISO VG 46.

Dari hasil pengujian pada sampel dengan kekentalan ISO VG 46 (tabel 4.5) dan kekentalam ISO VG 32 (tabel 4.6) menunjukkan bahwa semua sampel dengan komposisi yang berbeda dan pengamatan dilakukan selama 7 hari dengan suhu ruang dan suhu $65^{\circ} \mathrm{C}$ tidak ditemukan adanya endapan. Semua sampel tidak ada pemisahan dan terlihat bersih.

Hal ini menunjukkan bahwa bahan dasar dan aditif yang digunakan pada sampel yang diamati tidak terlalu jauh berbeda. Jenis sampel pelumas ini dapat dikatakan kompatibel dan tidak terjadi masalah apabila dilakukan pencampuran.

\section{KESIMPULAN}

\section{Kesimpulan}

Pada pengamatan selama tujuh hari pada keadaan suhu ruang dan suhu $65^{\circ} \mathrm{C}$ pada jenis oli mesin kekentalan monograde SAE 40 dan pelumas Multigrade (SAE 80W-90) dengan bahan dasar mineral dan mineral dari merk berbeda, sampel pelumas tidak ditemukan endapan dan tidak terjadi pemisahan. Sampel pelumas terlihat bersih pada semua komposisi campuran. Pada sampel jenis ini pelumas kompatibel dan tidak ada masalah pada mesin jika dilakukan pencampuran dengan komposisi berbeda. 
Pengujian dan pengamatan yang dilakukan pada sampel pelumas monograde SAE 40 dengan bahan dasar mineral dicampur dengan pelumas dengan bahan dasar sintetik dari merk berbeda ditemukan endapan pada komposisi campuran 50:50 dan 80:20 mulai hari ke-6 suhu $65^{\circ} \mathrm{C}$. Hal ini menunjukkan bahwa pelumas dengan bahan dasar berbeda tidak kompatibel jika dilakukan pencampuran.

Sampel pelumas dari jenis hidrolik yang diuji dan diamati selama tujuh hari pada suhu ruang dan suhu $65^{\circ} \mathrm{C}$, dari kedua sampel yang pelumas ISO VG 46 dan ISO VG 32 tidak terjadi pemisahan dan tidak ditemukan endapan pada semua komposisi campuran. Pelumas terlihat bersih. Hal ini menunjukkan kedua jenis pelumas kompatibel dan dapat dicampur karena terbuat dari bahan dasar dan aditif dari jenis yang sama.

\section{DAFTAR PUSTAKA}

[ASTM] American Standar of Testing and Materials. 2010. ASTM D 7155. Standard Practice for Evaluating Compatibility of Mixtures of Turbine Lubricating Oils. United States (US) : ASTM International.

Darmanto. 2011. Mengenal pelumas mesin. Momentum Jurnal, 6 (1).

Karina, R.M., \& Yuliani, C. 2010. Kompatibilitas Campuran Minyak Lumas Dasar Jenis Mineral dengan Minyak Nabati sebagai Minyak Lumas Dasar Pelumas Mesin Kendaraan Bermotor, Lembaran Publikasi Lemigas, 44 (3).

Marotrao, T. K. 2012. Physical Properties of Oil Blend and Their effects on Lubrication Properties. 2249-8974.

Mujiman. 2011. Pengukuran Nilai Viskositas Oli MESRAN SAE 10SAE50 Untuk Pendingin Transformator Distribusi dengan Penampil LCD. Jurnal Teknologi Technoscientia, 4(1), 1979-8415.
Nugrahani, R.A., 2007. Perancangan Proses Pembuatan Pelumas Dasar Sintetis Dari Minyak Jarak Pagar (Jatropha curcas L.) melalui Modifikasi Kimiawi. Disertasi Program Doktor. IPB

Siskayanti, R., \& Iridiastadi, H. 2014. Peningkatan Kualitas Produk Pelumas Industri Evalube Dengan Pendekatan Quality Function Deployment (QFD). Proceedings Seminar Nasional 2014, Entrepreneurship, Good Governance dan Reengineering Tata Lingkungan dalam Pembangunan Ekonomi Indonesia, Yogyakarta.

Siskayanti, R. 2015. Perbandingan Kinerja Pelumas Motor Skutik Mineral dan Sintetik pada Uji Jalan Sampai 6000 $\mathrm{Km}$. Jurnal Fakultas Teknik UMJ, 407-1846.

Siswanti. 2010. Pengaruh Penambahan Aditif Proses Daur Ulang Minyak Pelumas Bekas terhadap Sifat-sifat Fisis. Jurnal IImiah Jurusan Teknik Kimia EKSERGI, 10(2). 27-31.

Sukirno. 2010. Kuliah Teknologi Pelumas 3. Jakarta : Departemen Teknik Kimia Fakultas Teknik Universitas Indonesia. 
